\title{
Effect of photoperiod and heat stress in the third trimester of gestation on milk production and circulating hormones in dairy goats
}

\author{
S. J. Mabjeesh, ${ }^{* 1}$ C. Sabastian, ${ }^{*}$ O. Gal-Garber, ${ }^{*}$ and A. Shamay† \\ *Department of Animal Sciences, The Robert H. Smith Faculty of Agriculture, Food, and Environment, The Hebrew University of Jerusalem, \\ PO Box 12, Rehovot 76100, Israel \\ †Agricultural Research Organization, Volcani Center, Institute of Animal Science, Bet Dagan 50250, Israel
}

\begin{abstract}
The influence of photoperiod manipulation in the dry period was examined in dairy goats experiencing environmental heat stress. Multiparous Israeli Saanen goats were blocked at dry off ( $\sim 60 \mathrm{~d}$ prepartum) into 2 groups of 4 goats each based on body weight, previous milk production, and detected embryo number. Treatments consisted of long-day (16 h light:8 h dark) and short-day ( $8 \mathrm{~h}$ light:16 h dark) photoperiods (LDPP and SDPP, respectively). Heat-stress conditions were applied by manipulating the environment of metabolic rooms to reach a maximum temperature of $37^{\circ} \mathrm{C}$ between 1000 and $2200 \mathrm{~h}$, and a minimum of $23^{\circ} \mathrm{C}$ and $70.3 \%$ relative humidity. All goats were returned to ambient photoperiod after kidding, milked twice daily, and milk yield was automatically recorded. Dry matter intake during the dry period was similar between treatments, averaging 1,114 g/d. Milk production was significantly higher in the SDPP than the LDPP group $(2,172$ vs. $1,550 \mathrm{~g} / \mathrm{d})$ during the 12 -wk experimental period. Milk protein and fat contents were similar in both groups and averaged 3.63 and $4.34 \%$, respectively, whereas milk lactose was higher in the LDPP group ( 4.77 vs. $4.67 \%)$. Heart rates were similar between treatments and averaged 112.6 beats per minute (BPM). Respiration rates were lower in the morning (58.4 BPM) compared with the afternoon (91.2 BPM) and were not influenced by photoperiod. Rectal temperature was higher for the LDPP than the SDPP group $\left(40.4\right.$ vs. $39.6^{\circ} \mathrm{C}$ ). The thyroid hormone level (mean \pm SE) was similar in both groups during the dry period, but higher during lactation in the LDPP goats up to $40 \mathrm{~d}$ postpartum $(110 \pm 6.59$ vs. $156 \pm 8.76 \mathrm{ng} / \mathrm{mL})$. Plasma IGF-1 (mean \pm SE) was higher in the LDPP group (279 \pm 62 vs. $162 \pm 27 \mathrm{ng} / \mathrm{mL}$ in SDPP) during the dry period but was similar postkidding, averaging $132 \pm 24 \mathrm{ng} / \mathrm{mL}$. Plasma prolactin level (mean $\pm \mathrm{SE}$ )
\end{abstract}

Received April 16, 2012.

Accepted September 21, 2012.

${ }^{1}$ Corresponding author: Mabjeesh@agri.huji.ac.il was higher in the LDPP than the SDPP group during the dry period $(17.2 \pm 1.6$ vs. $10.6 \pm 0.99 \mathrm{ng} / \mathrm{mL})$, whereas it was similar throughout lactation $(0.61 \pm$ $0.28 \mathrm{ng} / \mathrm{mL}$ ). These data support the idea that SDPP manipulation during heat load in dry goats can be used as an abatement strategy to reduce the carryover effect of heat stress observed during the subsequent lactation. The higher milk production in SDPP goats is explained by changes in circulating prolactin profile rather than differences in feed intake or secretion of insulin-like growth factor 1.

Key words: dairy goat, heat stress, photoperiod, prolactin

\section{INTRODUCTION}

Dairy goat farming is on the rise in Israel and the Mediterranean region. Caprine milk production is gaining importance worldwide due to its health benefits for individuals suffering from allergies and intolerance to cow milk (Haenlein, 2004). In contrast to dairy cows, goats have seasonal reproductive cycles, but little information is available on the effects of environmental stressors such as heat and photoperiod on milk production and quality.

Dairy animals in Israel are exposed to heat stress for 3 to 4 mo a year. In recent years, most dairy goat management has turned to intensive regimens in which at least 2 breeding cycles are used: in one of these, the goats are bred in the early summer and suffer from heat stress during the third trimester of gestation under relatively long-day photoperiod (LDPP). We recently showed that dairy goats exposed to short-day photoperiod (SDPP; $8 \mathrm{~h}$ light:16 h dark) during the dry period produce more milk in the next lactation compared with LDPP goats (Mabjeesh et al., 2007). However, the effect of heat stress on goats during their third trimester in gestation has not been studied, in contrast to extensive studies of this phenomenon in dairy cows showing depressed milk yield, DMI, and reproductive performance (Beede and Collier, 1986; Wolfenson et al., 1988; do Amaral et al., 2009). Moreover, analy- 
ses of Israeli national records of Holstein cows have revealed that those exposed to heat stress in the summer months during the dry period (Barash et al., 2001) have the lowest annual milk yield. The prevailing view is that the reduction in milk yield under heat stress is a consequence of reduced appetite and DMI (Beede and Collier, 1986; Wolfenson et al., 1988; McGuire et al., 1989; West, 2003). However, this view has been challenged by evidence of a direct effect of heat stress itself on the process of milk secretion (Wayman et al., 1962; Bandaranayaka and Holmes, 1976): for example, force-feeding of hyperthermic cows to the level recorded in normothermic cows (Wayman et al., 1962) or restricting the intake of normothermic cows to the level recorded in hyperthermic cows (Bandaranayaka and Holmes, 1976) did not abolish the differences in milk yield between the two.

Both dairy cows and goats exposed to SDPP during the dry period produce more milk than their counterparts exposed to LDPP (16 h light:8 h dark) during the subsequent lactation (Dahl et al., 2000; Mabjeesh et al., 2007). The photoperiod effect observed in both dairy animals is mediated through the prolactin (PRL) signaling axis, in particular through the inverse relationship found between circulating PRL and its receptor (PRL-R) expression in multiple tissues, including the mammary gland (Auchtung et al., 2003, 2005; Dahl, 2008). Similar to LDDP during the dry period, heat stress increased the concentration of circulating PRL in dairy cows compared with cows under the same environmental conditions cooled by sprinklers and fans (Tao et al., 2011). Further, it was observed that cows experiencing heat stress during the dry period had increased circulating PRL and reduced mRNA gene expression of PRL-R in lymphocytes and hepatic tissue (do Amaral et al., 2009, 2010). Based on the data from Auchtung et al. (2003, 2005), mRNA gene expression of PRL-R in the mammary gland and lymphocyte tissues changes in the same direction; it can be concluded that heat stress has an effect similar to that of LDPP on mammary gland development and performance in subsequent lactations. Indeed, Tao et al. (2011) recently concluded that in dairy cows, experiencing heat stress during the dry period affects mammary gland development before parturition by showing a decrease in epithelial cell proliferation during the transition to lactation and, hence, decreased milk production.

Therefore, we hypothesized that dairy goats suffer from the same effects as dairy cows that are heat stressed during the dry period. We also hypothesized that the use of photoperiod manipulation would minimize the effect of heat stress during the dry period in dairy goats. To the best of our knowledge, no data are available regarding the influence of photoperiod and heat stress effects during the dry period in dairy goats. Photoperiod management is of great interest because it is a safe, noninvasive, and effective method of increasing milk production. The objectives of the current study were to evaluate the effects of heat stress under controlled photoperiod (LDPP vs. SDPP) during the dry period on subsequent milk production and plasma hormonal profiles in dairy goats.

\section{MATERIALS AND METHODS}

\section{Goats and Treatments}

All procedures were approved by the Hebrew University (Rehovot, Israel) Institutional Animal Care and Use Committee. Multiparous Israeli Saanen goats ( $\mathrm{n}=$ 8) in mid to late lactation were synchronized and inseminated to ensure their pregnancy. These goats were blocked at dry-off ( $\sim 60 \mathrm{~d}$ prepartum) into 2 treatments of 4 goats each based on BW, previous milk production, and the number of detected embryos in utero. Treatments were LDPP (16 h light:8 h dark) and SDPP (8 $\mathrm{h}$ light:16 h dark) at hyperthermic ambient temperature to induce heat stress (maximum of $37^{\circ} \mathrm{C}$ between 1000 and $2200 \mathrm{~h}$, minimum of $23^{\circ} \mathrm{C}$, and $70.3 \%$ relative humidity). All goats were maintained under ambient photoperiod until the onset of treatment. During the experimental period, goats were housed in separate metabolic rooms with fully controlled environmental conditions in metabolism cages equipped with automatic feeders. The photophase light intensity was 350 $\mathrm{lx}$ at goat eye level, with photoperiod adjusted according to treatment. Goats were fed a diet that adequately met their nutritional demands for maintenance and gestation stage. Feed was offered in 12 equal meals by automatic feeder. The diet consisted of commercial pellets containing $16 \% \mathrm{CP}, 29.1 \% \mathrm{NDF}$, and $1.6 \mathrm{Mcal}$ of $\mathrm{NE}_{\mathrm{L}}$ on a DM basis (mixture 1471; Ambar Ltd., Hadera, Israel), and chopped clover and vetch hay with $14.9 \% \mathrm{CP}, 47.5 \% \mathrm{NDF}$, and $1.1 \mathrm{Mcal}$ of $\mathrm{NE}_{\mathrm{L}}$. The hay supplied $60 \%$ of the daily DMI. Rectal temperature and heart and respiration rates were measured twice daily at 0700 and $1500 \mathrm{~h}$ by the MP 100 System (BIOPAC Systems Inc., Santa Barbara, CA).

Dry matter intake was monitored while the goats were in the metabolism cages and was adjusted to allow $10 \%$ refusals. At kidding, all goats were returned to ambient photoperiodic conditions and a normal management regimen. Goats were milked twice daily at 0700 and $1900 \mathrm{~h}$. Daily milk production was recorded by automatic milk meter for $12 \mathrm{wk}$ in lactation (WIL; Free-flow; S.E.R., Netanya, Israel). Pellets were offered in the milking parlor ad libitum and hay was then offered in the yards to supply $35 \%$ of total daily DMI. 
Blood samples were collected several times relative to kidding date (i.e., every $7 \mathrm{~d}$ from -60 to $+60 \mathrm{~d}$ ). Plasma was then separated and stored at $-20^{\circ} \mathrm{C}$ for later analysis of PRL, IGF-1, and triiodothyronine (T3). Milk composition was quantified weekly by a near-infrared procedure (MilkoScan 605; Foss Electric A/S, Hillerød, Denmark). Postkidding data were collected for $84 \mathrm{~d}$ postpartum, which was deemed sufficient time to detect any treatment differences.

\section{Hormone Analyses}

Blood samples $(10 \mathrm{~mL})$ were collected from each goat between 0830 and $1030 \mathrm{~h}$ via jugular venipuncture into a sterile evacuated tube containing sodium heparin (Vacutainer; Becton Dickinson and Co., Franklin Lakes, NJ), and immediately placed on ice. Plasma was harvested by centrifugation at $1,850 \times g$ for $20 \mathrm{~min}$ at $4^{\circ} \mathrm{C}$ and stored at $-20^{\circ} \mathrm{C}$ until use.

Radioimmunoassay for IGF-1 was performed as previously described (Plaut et al., 1991). Briefly, $250 \mu \mathrm{L}$ of plasma was extracted with $300 \mu \mathrm{L}$ of glycyl-glycine $\mathrm{HCl}$ $(0.1 \mathrm{M}, \mathrm{pH} 2)$ at $37^{\circ} \mathrm{C}$ for $24 \mathrm{~h}$. Twenty-five microliters of the extracted plasma and $100 \mu \mathrm{L}$ of anti-human IGF-1 (anti-hIGF-1; polyclonal primary antibody, NIH; GroPep Bioreagents Pty Ltd., Adelaide, Australia) were added to $275 \mu \mathrm{L}$ of assay buffer $(0.15 \mathrm{M}$ sodium phosphate, $0.02 \%$ protamine sulfate, $0.2 \% \mathrm{BSA}$, and $0.02 \%$ sodium azide $\mathrm{pH} 7.5$ ). After $1 \mathrm{~h}$ at room temperature, $100 \mu \mathrm{L}$ of ${ }^{125} \mathrm{IGF}-1(20,000 \mathrm{cpm})$ was added and the tubes were incubated for $24 \mathrm{~h}$ at $4^{\circ} \mathrm{C}$. Then, $100 \mu \mathrm{L}$ of a second antibody, goat anti-rabbit $\operatorname{IgG}$ in PBS containing $0.2 \%$ normal rabbit serum was added and incubation continued for another $24 \mathrm{~h}$ at $4^{\circ} \mathrm{C}$. The hormone-antibody complex was precipitated by the addition of $1 \mathrm{~mL}$ of $12 \%$ polyethylene glycol (PEG) 6000 (Sigma Chemical Co., St. Louis, MO) and centrifugation for $30 \mathrm{~min}$ at $4^{\circ} \mathrm{C}$ at $3,000 \times \mathrm{g}$. The supernatant was decanted and the assay precipitates were counted in a Kontron gamma counter (Kontron Israel, Tel Aviv, Israel) with a log-logit program. Intra- and interassay coefficients of variation were 5.7 and $8.7 \%$, respectively.

Concentrations of T3 were determined using an RIA kit according to the manufacturer's protocol (Diagnostic Products Corp., Los Angeles, CA). Intra- and interassay coefficients of variation were 5.8 and $9.2 \%$, respectively.

Prolactin RIA was performed as previously described (Miller et al., 1999), using primary antibody to PRL [AFPC35810691R; provided by A. F. Parlow, National Hormone and Pituitary Program (NHPP) and National Institute of Diabetes and Digestive and Kidney Diseases (NIDDK), Torrance, CA] diluted 1:50,000 in working solution and then to a final tube dilution of 1:200,000.
The intraassay coefficient of variation was $6.1 \%$ and the interassay coefficient of variation averaged $15.5 \%$. The assay sensitivity averaged $0.26 \mathrm{ng} / \mathrm{mL}$.

\section{Statistical Analysis}

Statistical analysis was performed using the mixed models procedures of SAS (version 8.2; SAS Institute Inc., Cary, NC). The model included treatment (LDPP vs. SDPP) and time as fixed variables, goat as the random variable, and their interaction. All dependent variables were included as repeated measures. If no interaction effects were detected, the model was reduced to include the main effects and the error term. Comparisons of means between treatments at various times (weeks) were performed using Student's $t$-test. Means are presented as least squares means.

\section{RESULTS}

\section{Goat Performance and Physiological Parameters}

All goats were healthy throughout the experimental period and all of their kids were healthy as well, although BW data were not recorded for each kid. Dry matter intakes (mean $\pm \mathrm{SE}$ ) during the dry period were similar between treatments, averaging $1,114 \pm 72 \mathrm{~g} / \mathrm{d}$.

Milk yield, monitored for 12 WIL, was higher in the SDPP group than in the LDPP group (Figure 1 and Table 1). Milk yields began to differ at wk 3 of lactation, being higher $(P<0.0001)$ in the SDPP group; averaged over the monitored lactation period, milk yield in the SDPP group was $620 \mathrm{~g} / \mathrm{d}$ higher than in the LDPP group (Table 1). Milk fat percentage tended $(P<0.11)$ to be higher in the SDPP than the LDPP group over the 12 -wk period and averaged $4.36 \%$ (Table 1). However, it was affected by week in lactation and was higher $(P<0.0001)$ in the SDPP group for the first 3 WIL (Figure 2A). An interaction effect occurred in the last 4 WIL, where the SDPP group had lower milk fat concentration than the LDPP group. Milk protein percentage, on the other hand, was similar in both treatments and averaged $3.63 \%$ (Table 1 and Figure 2B), and was reduced by week in lactation $(P$ $<0.0001)$. Milk lactose was similar for both groups throughout lactation but was $2 \%$ higher $(P<0.04)$ for the LDPP than the SDPP group. An interaction effect $(P<0.01)$ occurred with week in lactation because of reduced lactose concentration in the SDPP group during the last 4 WIL relative to the LDPP group (Figure $2 \mathrm{C})$.

Yields of milk components followed the same pattern as milk, being higher for the SDPP group $(P<0.0001$; Table 1 and Figure 3A-C) than the LDPP group. Milk 
protein was higher by $24.4 \mathrm{~g} / \mathrm{d}$, milk fat by $27.6 \mathrm{~g} / \mathrm{d}$, and milk lactose by $26.7 \mathrm{~g} / \mathrm{d}$.

Rectal temperature was similar during the 2 measurements $(0700$ and $1500 \mathrm{~h})$ but differed $(P<0.003)$ between treatments and was $40.4^{\circ} \mathrm{C}$ for LDPP and $39.6^{\circ} \mathrm{C}$ for SDPP goats (Table 2). However, both values were within the normal rectal temperature fluctuations for goats (data from the same breed measured in the goat house). Heart rate was similar between treatments and times of day and averaged 112.6 beats per minute (Table 2). Respiration rate measurements were not affected by photoperiod conditions, but were higher $(P$ $<0.003)$ at 1500 than $0700 \mathrm{~h}$ (58.4 vs. 91.2 beats per minute; Table 2).

\section{Plasma Hormones}

Plasma T3 levels (means $\pm \mathrm{SE}$ ) were similar between treatments during the 60-d period prepartum, averaging $110 \pm 6.59 \mathrm{ng} / \mathrm{mL}$ (Table 3). At kidding and up to $35 \mathrm{~d}$ afterward, plasma T3 levels were higher for the LDPP group, averaging $155.6 \pm 8.76 \mathrm{ng} / \mathrm{mL}$, and then decreased to $74.2 \pm 8.03 \mathrm{ng} / \mathrm{mL}$ in the last $35 \mathrm{~d}$ of the sampling period (Figure 4). The SDPP group had a constant level of circulating T3, averaging $116.0 \pm 17.6$ $\mathrm{ng} / \mathrm{mL}$ throughout the experimental period (Figure 4).

Plasma IGF-1 level was affected by treatment, being higher $(P<0.05)$ on average in the LDPP group than in the SDPP group during the experiment (Table $3)$. However, this difference was mainly based on the higher circulating IGF-1 during the $60 \mathrm{~d}$ prepartum in the LDPP group (Figure 5). After kidding, IGF-1 levels (mean $\pm \mathrm{SE}$ ) were similar for both groups, averaging $132.0 \pm 23.9 \mathrm{ng} / \mathrm{mL}$ (Figure 5).

Plasma PRL concentration (mean $\pm \mathrm{SE}$ ) was affected by photoperiod and weeks in lactation (Table 3): PRL was higher in the LDPP-treated animals than in their SDPP-treated counterparts, significantly so

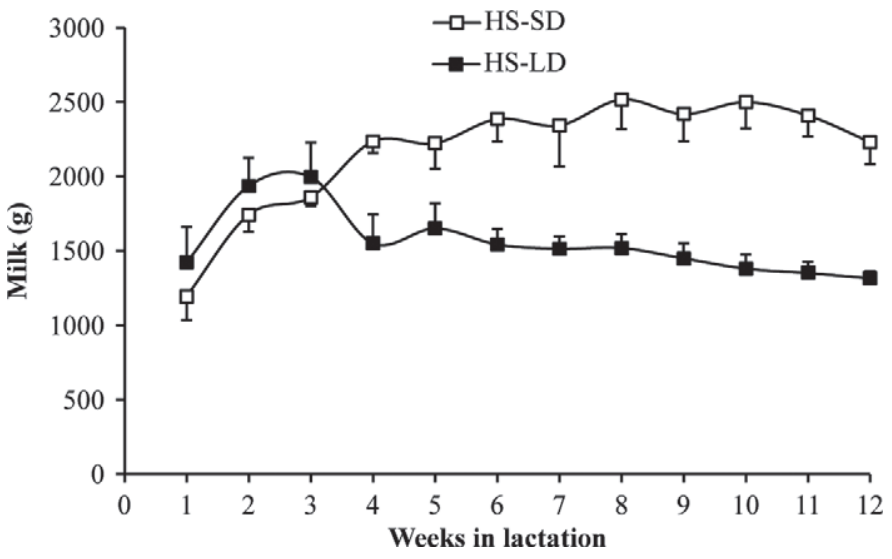

Figure 1. Milk yield of goats exposed to long-day (LD) photoperiod or short-day (SD) photoperiod during the third trimester of gestation under environmental heat stress (HS). Average milk production was significantly different between treatments from wk $4(\mathrm{SEM}=215$; $P<0.004)$. Error bars represent the SE.

from 35 to $10 \mathrm{~d}$ prepartum, averaging $17.2 \pm 1.60$ and $10.6 \pm 0.99 \mathrm{ng} / \mathrm{mL}$, respectively (Figure 6). Neither group exhibited a surge around kidding, but a dramatic reduction in plasma PRL concentration occurred from wk 2 postpartum through the end of the study $(0.61 \pm$ $0.28 \mathrm{ng} / \mathrm{mL}$; Figure 6).

\section{DISCUSSION}

In this study, we hypothesized that exposing dairy goats under environmental heat stress to SDPP during the dry period would lessen the carryover effects of the stress on milk production in the subsequent lactation compared with goats exposed to LDDP. Indeed, milk production in SDPP goats was $40 \%$ higher than in their LDPP counterparts. We previously showed that SDPP during the dry period increases subsequent milk production via changes in hormones (mainly PRL) that

Table 1. Milk yield and milk composition from dairy goats exposed to short-day photoperiod (SDPP) or longday photoperiod (LDPP) during the third trimester of gestation under environmental heat stress

\begin{tabular}{|c|c|c|c|c|c|}
\hline \multirow[b]{2}{*}{ Item } & \multicolumn{2}{|c|}{ Photoperiod } & \multirow[b]{2}{*}{ SEM } & \multicolumn{2}{|c|}{ Effect $^{1}$ ( $P$-value $)$} \\
\hline & LDPP & SDPP & & $\mathrm{PP}$ & WIL \\
\hline Milk (g/d) & 1,552 & 2,172 & 215 & $<0.0001$ & 0.15 \\
\hline Milk composition & & & & & \\
\hline Fat $(\mathrm{g} / \mathrm{d})$ & 65.7 & 93.3 & 11.6 & $<0.0001$ & 0.22 \\
\hline Protein (g/d) & 54.9 & 79.3 & 11.1 & $<0.0001$ & 0.99 \\
\hline $\operatorname{Lactose}^{2}(\mathrm{~g} / \mathrm{d})$ & 74.1 & 100.8 & 9.80 & $<0.0001$ & 0.11 \\
\hline Fat $^{3}(\%)$ & 4.24 & 4.47 & 0.34 & $<0.10$ & $<0.0001$ \\
\hline Protein (\%) & 3.57 & 3.68 & 0.36 & 0.47 & $<0.0001$ \\
\hline Lactose (\%) & 4.77 & 4.67 & 0.13 & 0.036 & 0.14 \\
\hline
\end{tabular}

${ }^{1} \mathrm{PP}=$ photoperiod; WIL $=$ week in lactation.

${ }^{2}$ Interaction effect of WIL $\times$ PP: $P<0.005$.

${ }^{3}$ Interaction effect of WIL $\times$ PP: $P<0.004$. 


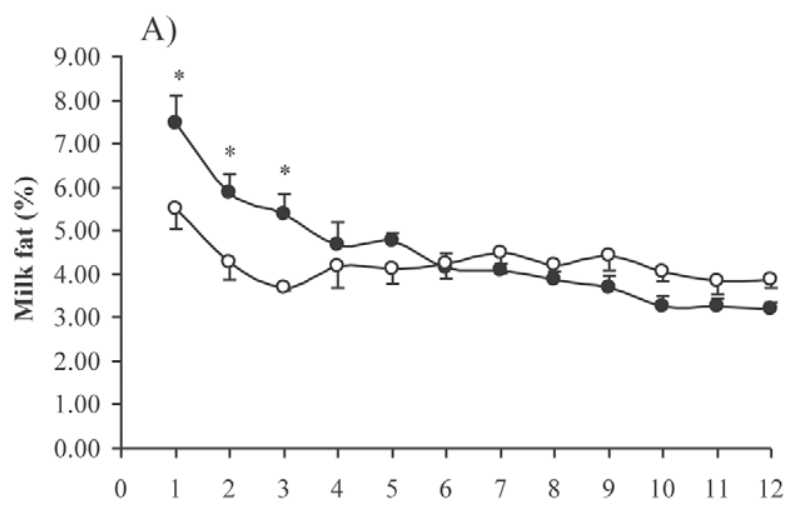

B)

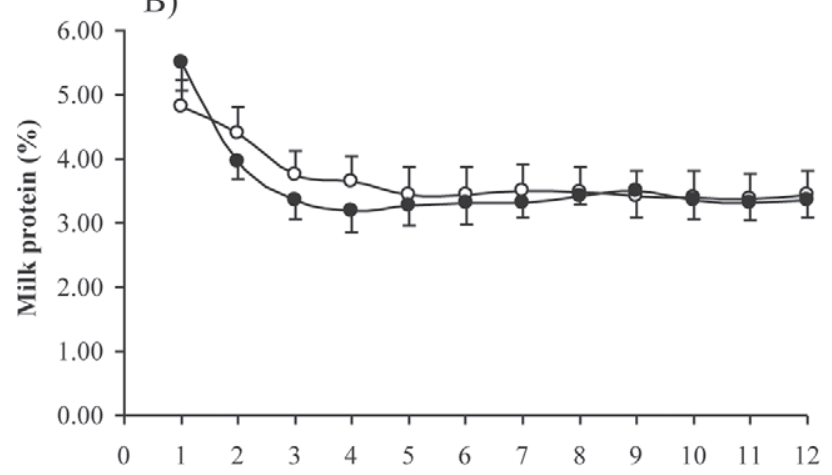

C)

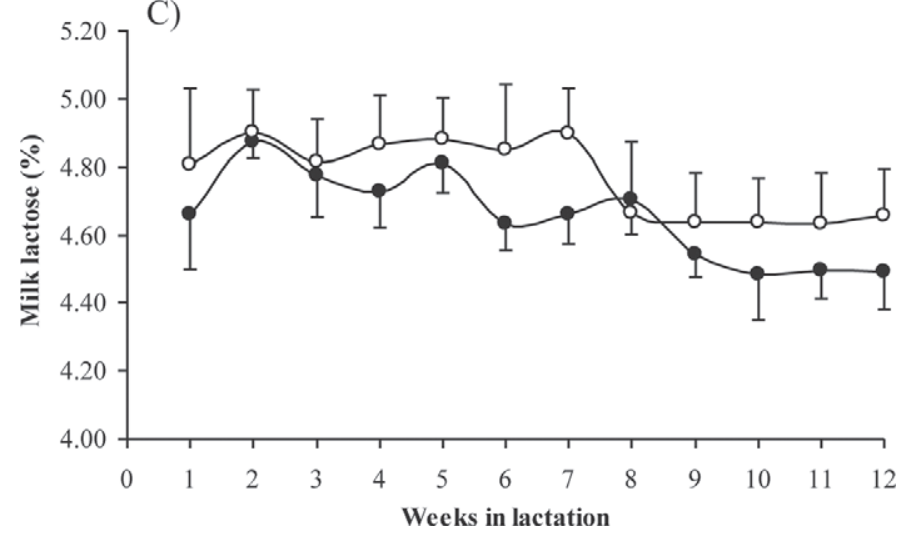

Figure 2. Percentage of milk fat (A), milk protein (B), and milk lactose (C) from goats exposed to long-day photoperiod (open circles) or short-day photoperiod (closed circles) during the third trimester of gestation under environmental heat stress $\left({ }^{*} P<0.05\right)$.

influence the mammary gland, rather than due to a general effect on feed intake (Mabjeesh et al., 2007).

Photoperiod did not affect DMI, which averaged $1,114 \mathrm{~g} / \mathrm{d}$ and was slightly higher than feed consumption $(980 \mathrm{~g} / \mathrm{d})$ observed for dry goats held at a comfortable environmental temperature (Mabjeesh et al., 2007). Hence, it can be assumed, as in the previous study, that feed intake and nutrient digestibility during the dry period under conditions of heat stress are similar to those under normothermal conditions. Goats,
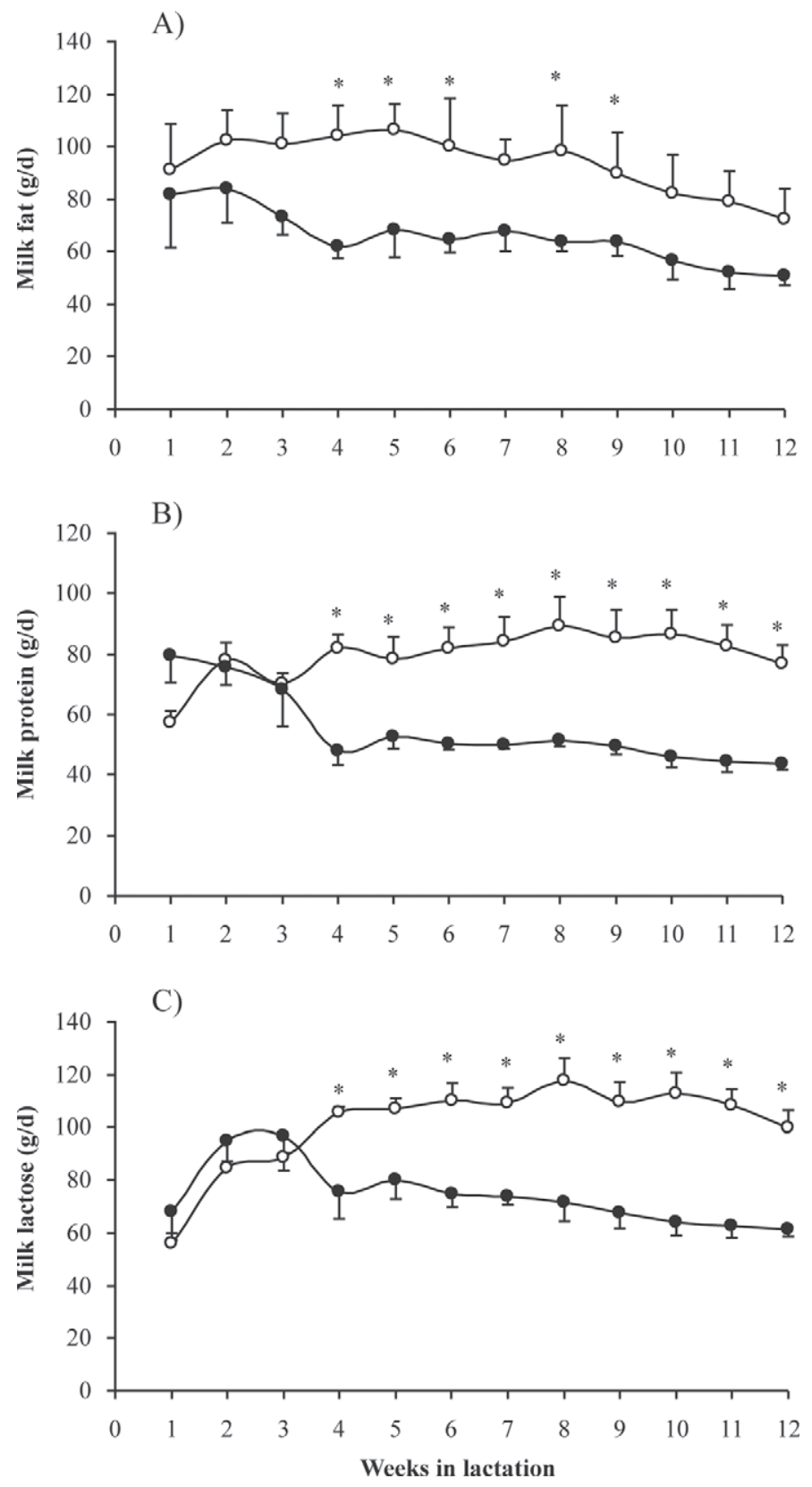

Figure 3. Milk fat (A), milk protein (B), and milk lactose (C) yields ( $\mathrm{g} / \mathrm{d}$ ) from goats exposed to long-day photoperiod (open circles) or short-day photoperiod (closed circles) during the third trimester of gestation under environmental heat stress $\left({ }^{*} P<0.05\right)$.

particularly local breeds, adapt well to high temperatures. However, they may still be susceptible to heat stress, as reflected by increasing tissue metabolism, heart, and respiration rates (Sahlu et al., 2004). Indeed, in the current study, goats maintained their heart rate and increased their respiration rate (panting) by $56 \%$ in the afternoon period (i.e., at maximum heat load) compared with the morning hours in both treatments. 
Table 2. Physiological parameters of dairy goats exposed to short-day photoperiod (SDPP) or long-day photoperiod (LDPP) during the third trimester of gestation under environmental heat stress, measured in the morning and afternoon

\begin{tabular}{|c|c|c|c|c|c|c|c|}
\hline Item $^{1}$ & \multicolumn{2}{|c|}{ Morning (0700 h) } & \multicolumn{2}{|c|}{ Afternoon (1500 h) } & SEM & \multicolumn{2}{|c|}{ Effect $^{2}$ ( $P$-value $)$} \\
\hline Respiration rate (BPM) & 57.5 & 59.2 & 93.0 & 89.3 & 6.28 & 0.003 & 0.76 \\
\hline Rectal temperature $\left({ }^{\circ} \mathrm{C}\right)$ & 40.2 & 39.5 & 40.6 & 39.6 & 0.16 & 0.23 & 0.003 \\
\hline
\end{tabular}

${ }^{1} \mathrm{BPM}=$ beats or breaths per minute.

${ }^{2} \mathrm{PP}=$ photoperiod. No interaction effect of time $\times \mathrm{PP}$ was observed.

Similar findings have been observed in dry noncooled Holstein dairy cows under heat load (Adin et al., 2009), but their respiration breathing rates only increased by 20 and $11 \%$ between the morning and the afternoon measurements in 2 different experiments. Similarly in lactating Jersey cows, heat stress increased respiration rate by $28 \%$ (Keister et al., 2002). This physiological difference in response might be attributed to the goats' acclimatization ability compared with dairy cows (Sahlu et al., 2004) and to the metabolic body size differences between species. Interestingly, goats under both photoperiods maintained rectal temperatures within the normal range (measured for the entire local herd in the goat house) during the day; nevertheless, they were $0.8^{\circ} \mathrm{C}$ higher in the LDPP group than the SDPP group. This suggests that goats under SDPP coped better with the heat load compared with the LDPP group. This phenomenon, together with increased milk production in the subsequent lactation, suggests that the effect of SDPP is mediated hormonally.

Exposing goats under heat stress to different photoperiodic regimens resulted in changes in hormonal profile, similar to our previous findings (Mabjeesh et al., 2007). The hormones measured in the current study (T3, IGF-1, and PRL) are relevant to, and could explain the differences in subsequent milk production. Lactating cows exposed to LDPP have greater IGF-1 concentrations than cows exposed to ambient natural photoperiod (Dahl et al., 1997). In this study, plasma IGF-1 concentration was also affected by photoperiod: it was higher in goats exposed to LDPP relative to
SDPP during the dry period. Nonetheless, IGF-1 concentration was similar after kidding and during lactation in both groups. The IGF-1 profile in the LDPP group prepartum (this study) differed from that observed in LDPP goats under thermoneutral environmental conditions (Mabjeesh et al., 2007), being higher throughout the entire dry period. Under heat stress conditions, IGF-1 concentration was higher from -35 to $-20 \mathrm{~d}$ relative to day of kidding, increased rapidly to its peak at parturition, and then dropped back down to basal levels after kidding. The SDPP group showed a constant level of IGF-1 throughout the experimental period in both the current and previous study. Strong evidence exists supporting the stimulatory effect of long days on IGF-1 secretion in ruminants, thus providing a possible endocrine mechanism to explain the photoperiod effects on growth (Dahl et al., 2000). This has been shown in prepubertal heifers exposed to LDPP for 4 mo (Spicer et al., 1994), which consistently showed greater circulating IGF-1 levels relative to animals held under SDPP. It has also been determined that long days increase mammary parenchymal growth relative to short days (Petitclerc et al., 1984), and that IGF-1 increases bovine mammary growth in vitro (McGrath et al., 1991; Shamay et al., 1988). It has also been reported that LDPP increases IGF-1 at the level of its secretion, rather than via altered clearance or growth hormone stimulation. Thus, the galactopoietic effect of LDPP in an established lactation might be driven by the increased concentration of IGF-1 in the circulation (Dahl et al., 1997). However, despite the goats' expo-

Table 3. Plasma hormone concentrations of dairy goats exposed to short-day photoperiod (SDPP) or long-day photoperiod (LDPP) during the third trimester of gestation under environmental heat stress

\begin{tabular}{|c|c|c|c|c|c|}
\hline \multirow[b]{2}{*}{ Item $^{1}$} & \multicolumn{2}{|c|}{ Photoperiod } & \multirow[b]{2}{*}{ SEM } & \multicolumn{2}{|c|}{ Effect $^{2}(P$-value $)$} \\
\hline & LDPP & SDPP & & $\mathrm{PP}$ & WIL \\
\hline Prolactin $(\mathrm{ng} / \mathrm{mL})$ & 6.70 & 5.55 & 1.48 & 0.05 & $<0.001$ \\
\hline IGF-1 (ng/mL) & 213.7 & 152.0 & 82.7 & 0.05 & 0.36 \\
\hline $\mathrm{T} 3(\mathrm{ng} / \mathrm{mL})$ & 118.4 & 116.0 & 12.2 & 0.59 & $<0.0001$ \\
\hline
\end{tabular}




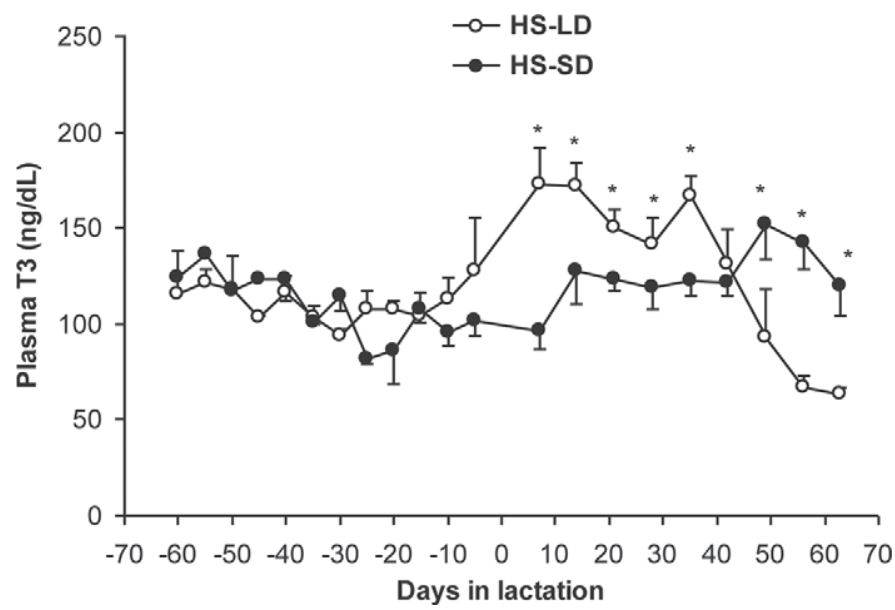

Figure 4. Plasma triiodothyronine (T3) concentration in goats exposed to long-day (LD) photoperiod or short-day (SD) photoperiod during the third trimester of gestation under environmental heat stress (HS; SEM $=12.2 ; P<0.59$ for photoperiod and $P<0.0001$ for week in lactation effects). $*$ indicates a significant effect of photoperiod.

sure to LDPP during the dry period and the significant increase in IGF-1 in the circulation, milk yield was $40 \%$ higher in the SDPP group. Taken together, the results of this study and previous ones in dairy goats (Mabjeesh et al., 2007) and cows (Miller et al., 2000) suggest that the effect of manipulating photoperiod during the dry period under conditions of heat stress is not mediated by changes in IGF-1.

In dry dairy cows, heat stress has been reported to affect hormonal profile and increase PRL concentration in the circulation (Tao et al., 2011). As expected, plasma PRL concentration in LDPP goats was higher up to

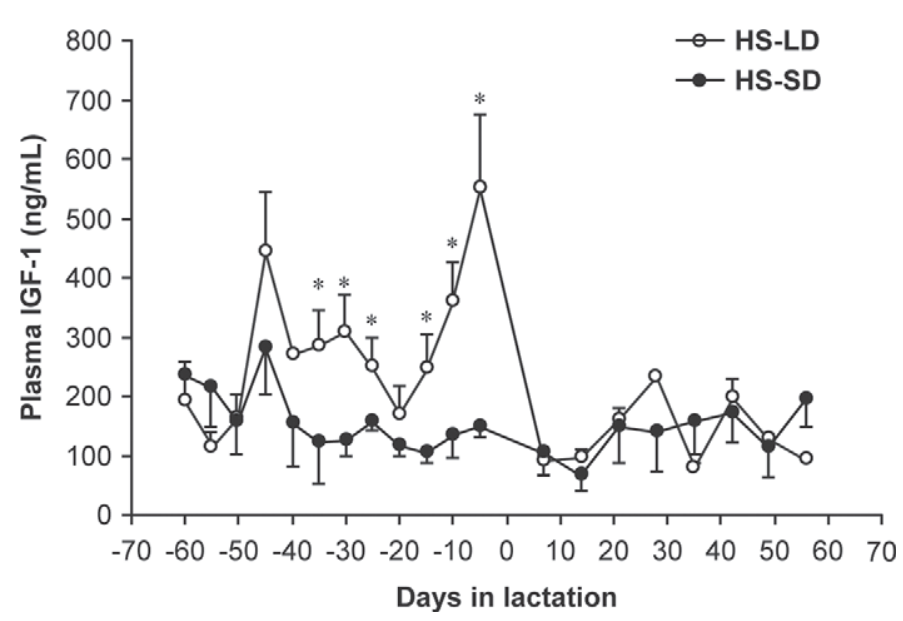

Figure 5. Plasma IFG-1 concentration in goats exposed to longday (LD) photoperiod or short-day (SD) photoperiod during the third trimester of gestation under environmental heat stress (HS; SEM = 82.7; $P<0.052$ for photoperiod and $P<0.36$ for week in lactation effects). * indicates a significant effect of photoperiod.

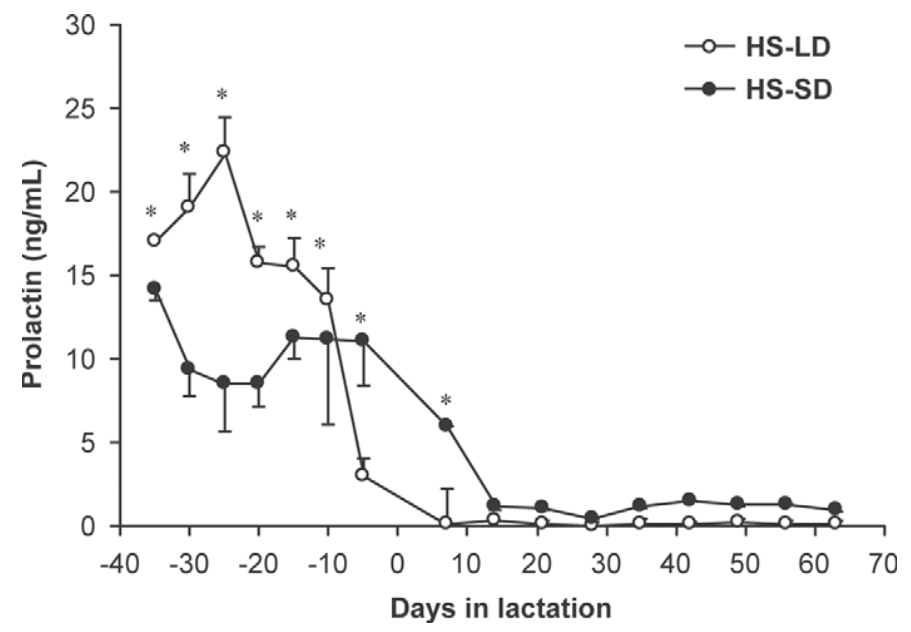

Figure 6. Plasma prolactin concentration in goats exposed to longday (LD) photoperiod or short-day (SD) photoperiod during the third trimester of gestation under environmental heat stress (HS; SEM = 1.48; $P<0.046$ for photoperiod and $P<0.001$ for week in lactation effects). ${ }^{*}$ indicates a significant effect of photoperiod.

$10 \mathrm{~d}$ prepartum and then decreased to basal levels for the remainder of the experimental period; on the other hand, the SDDP goats showed higher PRL concentrations at -10 to -8 d relative to kidding compared with their LDPP counterparts. This profile differed from the previous study in which PRL was higher in LDPP goats than in SDPP goats under normothermal environmental conditions throughout the entire dry period (Mabjeesh et al., 2007). In that study, PRL concentration peaked at parturition in both groups, and was higher in the LPDD group, but milk production remained higher in the SDPP group. Under SDPP in the current study, plasma PRL concentration decreased and was eventually suppressed relative to the LDPP group, but it was still higher in the close-up period relative to parturition and $8 \mathrm{~d}$ thereafter. This PRL profile in the SDPP goats resembles the semi-peak observed in goats under comfortable conditions. Prolactin is critically important to the secondary stage of lactogenesis, which occurs at parturition (Akers, 1985). It is also necessary for complete differentiation of the bovine mammary secretory epithelial cells at the time of parturition on the surface membrane of the mammary epithelial cell (Frantz et al., 1974; Tucker, 2000). Following binding, a cascade of events initiate that eventually turn on transcription of the genes that regulate the secretion of milk proteins (Tucker, 2000). Bovine tissues express at least 2 forms of PRL-R: long and short (Schuler et al., 1997). It has been shown, in steers and dry cows, that LDPP and heat stress increase the concentrations of PRL and decrease its receptors in different tissues (Auchtung et al., 2003; do Amaral et al., 2009, 2010). Steers exposed to 
LDPP had higher PRL concentrations and lower PRL$\mathrm{R}$ mRNA expression in the liver, mammary gland, and lymphocytes, whereas the opposite effect was observed with SDPP treatment. Recently, this inverse relationship between PRL concentration and PRL-R expression in the mammary gland was confirmed in dairy cows exposed to photoperiod treatments during the dry period (Auchtung et al., 2005). Furthermore, it was suggested that because PRL and PRL-R influence the mammogenic ability of mammary cells to produce milk components, it is likely that shifts in PRL sensitivity alter the extent of cellular differentiation and proliferation during the transition period and thus decrease milk production in the subsequent lactation (Tao et al., 2011). Because all goats in the present study were moved to ambient photoperiod and temperature after kidding, it is possible that heat-stressed goats under SDPP expressed more PRL-R in the mammary gland, and the parturient PRL semi-surge, together with the relative shift in photoperiod, dramatically stimulated the parenchymal cells, which led to a higher lactogenic response. Expression of PRL-R was not measured in the current study; however, the goats' milk production began to differ at wk 3 postkidding, implying an effect of PRL binding to its receptors, which would initiate the observed lactogenic response. However, the SDPP goats produced $620 \mathrm{~g} / \mathrm{d}$ more milk than their counterparts under LDPP conditions, but still did not reach their full genetic production profile (Mabjeesh et al., 2007). This implies that PRL and PRL-R are probably not the sole hormonal effectors responsible for milk production under the current experimental conditions.

Plasma T3 concentrations during the prepartum period were not affected by photoperiod and were similar in both groups. This might be related to equal metabolic demands and challenges, as evidenced by equal DMI. This observation is similar to that reported in dry goats exposed to either SDPP or LDPP under thermoneutral environmental conditions (Mabjeesh et al., 2007). However, the T3 level was higher in the LDPP group from d 10 to 40 postpartum and decreased from d 50 to 70 of lactation compared with the SDPP group. In dairy cows and goats, higher plasma T3 concentration postpartum parallels enhanced metabolic priority and nutrient partitioning to the mammary gland (Tucker, 2000; Mabjeesh et al., 2007). Moreover, plasma T3 concentration is lower in dairy cows with low energy intake (Ronge et al., 1988). The hormonal profile in the current study cannot be explained as a consequence of higher metabolic demand in the LDPP group, at least not as a result of increased requirements for milk synthesis and secretion. However, it might be a consequence of a carryover effect of heat stress experienced by the goats during the dry period under LDPP.

\section{CONCLUSIONS}

Exposure of dairy goats under heat stress to SDPP during the dry period increased milk production in the subsequent lactation compared with LDPP exposure. The SDPP seems to neutralize the heat stress effects via the PRL axis. Sensitivity to PRL, particularly during the transition to lactation, may be the mechanism underlying the higher milk yield observed throughout the subsequent lactation.

\section{ACKNOWLEDGMENTS}

This research was funded by the US-Israel Binational Agricultural Research and Development Fund (Bet Dagan, Israel; award no. US-3201-01).

\section{REFERENCES}

Adin, G., A. Gelman, R. Solomon, I. Flamenbaum, M. Nikbachat, E. Yosef, A. Zenou, A. Shamay, Y. Feuermann, S. J. Mabjeesh, and J. Miron. 2009. Effects of cooling dry cows under heat load conditions on mammary gland enzymatic activity, intake of food and water, and performance during the dry period and after parturition. Livest. Sci. 124:189-195.

Akers, R. M. 1985. Lactogenic hormones: Binding sites, mammary growth, secretory cell differentiation, and milk biosynthesis in ruminants. J. Dairy Sci. 68:501-519.

Auchtung, T. L., P. E. Kendall, J. L. Salak-Johnson, T. B. McFadden, and G. E. Dahl. 2003. Photoperiod and bromocriptine treatment effects on expression of prolactin receptor mRNA in bovine liver, mammary gland and peripheral blood lymphocytes. J. Endocrinol. 179:347-356.

Auchtung, T. L., A. G. Rius, P. E. Kendall, T. B. McFadden, and G. E. Dahl. 2005. Effects of photoperiod during the dry period on prolactin, prolactin receptor, and milk production of dairy cows. J. Dairy Sci. 88:121-127.

Bandaranayaka, D. D., and C. W. Holmes. 1976. Changes in the composition of milk and rumen contents in cows exposed to a high ambient temperature with controlled feeding. Trop. Anim. Health Prod. 8:38-46.

Barash, H., N. Silanikove, A. Shamay, and E. Ezra. 2001. Interrelationships among ambient temperature, day length, and milk yield in dairy cows under a Mediterranean climate. J. Dairy Sci. $84: 2314-2320$

Beede, D. K., and R. J. Collier. 1986. Potential nutritional strategies for intensively managed cattle during thermal stress. J. Anim. Sci. 62:543-554.

Dahl, G. E. 2008. Effects of short day photoperiod on prolactin signaling in dry cows: A common mechanism among tissues and environments? J. Anim. Sci. 86:10-14.

Dahl, G. E., B. A. Buchanan, and H. A. Tucker. 2000. Photoperiodic effects on dairy cattle: A review. J. Dairy Sci. 83:885-893.

Dahl, G. E., T. H. Elsasser, A. V. Capuco, R. A. Erdman, and R. R. Peters. 1997. Effects of a long daily photoperiod on milk yield and circulating concentrations of insulin-like growth factor-1. J. Dairy Sci. 80:2784-2789.

do Amaral, B. C., E. E. Connor, S. Tao, J. Hayen, J. Bubolz, and G. E. Dahl. 2009. Heat-stress abatement during the dry period: Does cooling improve transition into lactation? J. Dairy Sci. 92:59885999

do Amaral, B. C., E. E. Connor, S. Tao, J. Hayen, J. Bubolz, and G. E. Dahl. 2010. Heat stress abatement during the dry period influences prolactin signaling in lymphocytes. Domest. Anim. Endocrinol. $38: 38-45$. 
Frantz, W. L., J. H. MacIndoe, and R. W. Turkington. 1974. Prolactin receptors: Characteristics of the particulate fraction binding activity. J. Endocrinol. 60:485-497.

Haenlein, G. F. W. 2004. Goat milk in human nutrition. Small Rumin. Res. 51:155-163.

Keister, Z. O., K. D. Moss, H. M. Zhang, T. Teegerstrom, R. A. Edling, R. J. Collier, and R. L. Ax. 2002. Physiological responses in thermal stressed Jersey cows subjected to different management strategies. J. Dairy Sci. 85:3217-3224.

Mabjeesh, S. J., O. Gal-Garber, and A. Shamay. 2007. Effect of photoperiod in the third trimester of gestation on milk production and circulating hormones in dairy goats. J. Dairy Sci. 90:699-705.

McGrath, M. F., R. J. Collier, D. R. Clemmons, W. H. Busby, C. A. Sweeny, and G. G. Krivi. 1991. The direct in vitro effect of insulin-like growth factors (IGFs) on normal bovine mammary cell proliferation and production of IGF binding proteins. Endocrinology 129:671-678.

McGuire, M. A., D. K. Beede, M. A. DeLorenzo, C. J. Wilcox, G. B Huntington, C. K. Reynolds, and R. J. Collier. 1989. Effects of thermal stress and level of feed intake on portal plasma flow and net fluxes of metabolites in lactating Holstein cows. J. Anim. Sci. 67:1050-1060.

Miller, A. R., R. A. Erdman, L. W. Douglass, and G. E. Dahl. 2000. Effects of photoperiodic manipulation during the dry period of dairy cows. J. Dairy Sci. 83:962-967.

Miller, A. R., E. P. Stanisiewski, R. A. Erdman, L. W. Douglass, and G. E. Dahl. 1999. Effects of long daily photoperiod and bovine somatotropin (Trobest) on milk yield in cows. J. Dairy Sci. $82: 1716-1722$.

Petitclerc, D., L. T. Chapin, and H. A. Tucker. 1984. Carcass composition and mammary development responses to photoperiod and plane of nutrition in Holstein heifers. J. Anim. Sci. 58:913-919.

Plaut, K., W. S. Cohick, D. E. Bauman, and R. C. Baxter. 1991 Evaluation of interference by insulin-like growth factor I (IGF-I) binding proteins in a radioimmunoassay for IGF-I in serum from dairy cows. Domest. Anim. Endocrinol. 8:393-405.
Ronge, H., J. Blum, C. Clement, F. Jans, H. Leuenberger, and H. Binder. 1988. Somatomedin C in dairy cows related to energy and protein supply and to milk production. Anim. Prod. 86:165-183.

Sahlu, T., A. L. Goetsch, J. Luo, I. V. Nsahlai, J. E. Moore, M. L. Galyean, F. N. Owens, C. L. Ferrell, and Z. B. Johnson. 2004. Nutrient requirements of goats: Developed equations, other considerations and future research to improve them. Small Rumin. Res. 53:191-219.

Schuler, L. A., R. J. Nagel, J. Gao, N. D. Horseman, and M. A. Kessler. 1997. Prolactin receptor heterogeneity in bovine fetal and maternal tissues. Endocrinology 138:3187-3194.

Shamay, A., N. Cohen, M. Niwa, and A. Gertler. 1988. Effect of insulin-like growth factor I on deoxyribonucleic acid synthesis and galactopoiesis in bovine undifferentiated and lactating mammary tissue in vitro. Endocrinology 123:804-809.

Spicer, L. J., B. A. Buchanan, L. T. Chapin, and H. A. Tucker. 1994 Effect of 4 months of exposure to various durations of light on serum insulin-like growth factor-1 (IGF-1) in prepubertal Holstein heifers. J. Anim. Sci. 72(Suppl. 1):178. (Abstr.)

Tao, S. J. W. Bubolz, B. C. do Amaral, I. M. Thompson, M. J. Hayen, S. E. Johnson, and G. E. Dahl. 2011. Effect of heat stress during the dry period on mammary gland development. J. Dairy Sci. 94:5976-5986

Tucker, H. A. 2000. Hormones, mammary growth, and lactation: A 41-year perspective. J. Dairy Sci. 83:874-884.

Wayman, O., H. D. Johnson, C. P. Merilan, and I. L. Berry. 1962. Effect of ad libitum or force-feeding of two rations on lactating dairy cows subject to temperature stress. J. Dairy Sci. 45:1472-1478.

West, J. W. 2003. Effects of heat-stress on production in dairy cattle. J. Dairy Sci. 86:2131-2144.

Wolfenson, D., I. Flamenbaum, and A. Berman. 1988. Dry period heat stress relief effects on prepartum progesterone, calf birth weight, and milk production. J. Dairy Sci. 71:809-818. 